\title{
A Contribution to the Life-history of Viola.
}

\author{
BY
}

\author{
MARY C. BLISS.
}

With Plates XVII-XIX.

\section{INTRODUCTION AND METHODS.}

THE present study is based upon an investigation of the chasmogamic 1 flowers of Viola odorata, Viola pedata, Viola fimbriatula, Viola cucullata, and Viola pubescens. Of these $V$. cucullata and $V$. pedata were found to be the most favourable species for study. The ovules are larger than in the other species, and the structures of the embryo-sac are less difficult to determine. The cleistogamous flowers were studied only by way of comparison, and offered no interesting differences as regards the development of the embryo-sac up to the eight-nucleate stage. Beyond this stage, the development of the female gametophyte in these flowers was not observed. Material has been collected for a comparative study of the floral parts of the cleistogamic and chasmogamic flowers, and it is my purpose to determine, if possible, the causes and conditions which operate to produce the cleistogamic flowers or which tend to modify the structure of the chasmogamic flower. It is interesting to note that violet plants transplanted from the open to the greenhouse in early spring produced only a few chasmogamic flowers and many cleistogamous flowers, but often transitional forms were developed, cleistogamous flowers with rudimentary petals and with more than the usual two stamens. The details of these phenomena will be considered in a later paper.

The material for this present work was collected in Wellesley and Needham from March Io to May 27, 1903, and in Philadelphia from March 25 to May I, I908. Long before the first signs of leaves appeared in most of the species, $V$. odorata was in bud. The buds of the other species appeared in the following order: $V$. fimbriatula, $V$. cucullata, $V$. pedata, and $V$. pubescens. Buds of various sizes were collected and classified under the following heads : smallest buds, colourless, embedded in the crown of the root-stock; buds green, medium; buds larger, but still wholly green; buds with corolla visible; buds just opening and buds half 
open. From this point, flowers from one to five days open and withered flowers were collected. The buds collected in Philadelphia were measured for greater accuracy.

In order to determine the exact age of a flower at a certain stage of structural development, the buds were tagged in the open field with a tiny square of white paper tied to the stem by a thread. For instance, fifty buds which were to open the next day were tagged with the number $I$, and this number with date of tagging was recorded in a notebook. The next day some of the flowers were collected and fixed; others from the same group were collected on the second and third days and so on. In this way about a thousand violets were tagged and collected. The following table shows stages of structural development and relative size of bud or age of open flower.

\section{Table showing Relative Size of Bud and Stage of Development.}

\section{Buds.}

Buds smallest, colourless. V. cucullata.

Buds medium, green. $\quad V$. pedata.

Buds small, green. $V$. odorata.

Buds large, corolla not visible. $\quad$. cucullata.

Buds large, corolla visible. V. cucullata.

Buds large, corolla not visible. $V$. pedata.

Buds just opening. $V$. cucullata.

Buds just opening. V. fimbriatula.

Buds just opening. $V$. pubescens.

Flowers first day open. $\quad V$. cucullata.
Oogenesis.

Placenta differentiated. Ovular papillae not yet visible.

Ovular papillae developed.

Ovule nearly anatropous; integuments visible, archesporial cell differentiated, tapetal cell cut off.

Second division of tapetal cell. Megaspore-mother-cell in prophase of division.

Growth of functional megaspore.

Two-celled embryo-sac.

Four-celled embryo-sac,

Eight-celled embryo-sac.

Fusion of polar nuclei.

Presence of pollen-tubes. Stages in fertilization. Division of endosperm.

Two fixing fluids were used, Flemming's chrom-osmo-acetic acid and chrom-acetic-acid solutions. Both gave good results. The pistils were removed from the bud and the ovaries only fixed. The wall of the larger ovaries was cut away so that the fixing fluid might penetrate more quickly to the ovules. In some cases, the style was left in position in order that the path of the pollen-tube might be traced. Some of the buds collected were so small that it was impossible to dissect out the ovaries. These buds were fixed whole, and in section offer an interesting comparison of relative microsporangial and macrosporangial development. Two stains, Flemming's triple stain and Heidenhain's iron-alum haematoxylin, were used. Both gave good results. 


\section{ORIGIN OF OVULES.}

The ovary of the Violaceae is unilocular with three parietal placentae. At a very early stage the placental line is recognized by a layer of closely set cells differing from the other cells in their denser and more deeply staining cytoplasm. Very soon the placenta becomes more conspicuous by the rapid growth of the cells directly back of the placental region, so that the line of placentation extends out into the cavity of the ovary. It is interesting to note that before the primordial cells of the ovule are visible, the anther lobes are well developed, the cells of the tapetal and the sporogenous tissue are clearly differentiated, and the spore-mother-cells are in the early prophase of the heterotypic division. The ovules arise as minute papillae on the placenta, and at first grow directly out into the cavity of the ovary. Soon, however, the ovule became anatropous.

\section{Differentiation of ARChesporium and TApetum.}

The primary archesporial cell is hypodermal in origin, and is differentiated before the ovule has become anatropous. This cell differs from the cells of the surrounding tissue by its greater size, denser cytoplasm, and larger nucleus (Pl. XVII, Fig. I). A transverse division soon cuts off a tapetal cell from the primary archesporial cell (Fig. 2). The tapetal cell may divide first by an anticlinal or by a periclinal wall (Figs. 2, 3). Further divisions of the tapetal cells are variable, but finally a cap of considerable depth is formed, and the definitive archesporial cell comes to occupy a central position in the nucellus (Fig. 4). In Viola, the nucellar cap persists up to the time of embryo formation, and at the time of fertilization the pollentube makes its way through this tissue in its passage from the micropyle to the egg.

The interesting phenomenon of twin nucelli was noted in several preparations. In one preparation observed, the embryo-sac was developed in each nucellus as far as the eight-nucleate stage, and the egg apparatus had been established. If in such cases fertilization should take place, we would have a case of polyembryony in Viola, or according to Ernst (4) a case of pseudo-polyembryony, brought about by the division of the nucellus at an early stage of development.

\section{Formation of the Axial Row.}

During the formation of the tapetal tissue the definitive archesporial cell increases in size, its cytoplasm becomes scanty, and the nucleolus appears as a densely staining granular mass of chromatin (Fig. 3). At this time the cells of the nucellus surrounding the archesporial cell are actively dividing. In the nuclear plate stage of the first division, the macrospore- 
mother-cell has increased to several times its original size, and occupies a central position in the nucellus. Its cytoplasm is very scanty, except in the region of the spindle. In some cases the macrospore-mother-cell has elongated to twice its width at the metaphase of the first division, but often the cell is still spherical as in the early prophase of division (Fig. 4).

At the close of the first division a distinct cell-wall is laid down, giving rise to two cells of nearly equal size (Fig. 5). Each of these two cells divides, and the result is an axial row of four cells. The development of the axial row in Viola differs from that described for Trillium by Coulter and Chamberlain (2), for Houstonia by Lloyd (6), for Larix by Juel (5), and for the great majority of Angiosperms as described by other writers, in that the upper daughter-cell, the one nearest the micropyle, divides first.

The cells of the axial row in Viola are not always arranged in a vertical row as represented in Fig. 6, but the walls may be laid down obliquely (Fig. 8), resulting in a group of cells in which the arrangement of the macrospores more nearly approaches the tetrad arrangement characteristic of typical spore formation. In this respect, the arrangement of the cells in the axial row in Viola corresponds to the arrangement figured for Delphinium (Mottier, 7), and for Fatsia japonica (Ducamp, 3). In Viola, generally the lower megaspore, the one furthest removed from the micropyle, is the functional megaspore, and develops into the embryo-sac. This order of development, however, was not invariable. Cases were observed in which the third megaspore became the functional megaspore (Pl. XVIII, Fig. IO), and still others in which, although the second and third cells increased equally in size for some time, the second without doubt was to develop into the embryo-sac. That the other cells of the axial row are disentegrating at this time is evidenced by the densely staining irregular masses of cytoplasm (Fig. II).

\section{Development of the Female Gametophyte.}

During the rapid growth of the functional megaspore, the dense cytoplasm of its early development becomes vacuolate. Preparatory to its germination the nucleus moves from a central position in the cell to the micropylar end. At this stage, the mother-cell of the embryo-sac extends nearly one-third the length of the nucellus. The changes subsequent to the formation of the axial row take place rapidly, the integuments very soon extend to the top of the nucellus, and in Fig. 12 are just beginning to curve, preparatory to enclosing it. In the two-celled embryo-sac shown in Fig. I2 A, the nucleus has divided and the two daughter nuclei have separated, one nucleus remaining at the micropylar end of the sac, while the other has passed to the extreme opposite pole. The two nuclei are connected by strands of cytoplasm, and there is a slight condensation of cytoplasm at both poles and at the periphery of the embryo-sac. In the central portion 
of the sac is an irregular vacuole, two-thirds as long as the entire embryo-sac.

The embryo-sac continues to lengthen and broaden, the nuclei at either pole divide simultaneously, and the four-nucleate stage is established. At this stage, the embryo-sac is twice as long as at the two-nucleate stage, but the comparative length and breadth are the same. The third division soon follows, and gives rise to the typical eight-nucleate embryo-sac of Angiosperms. Immediately after this division, the three cells which are to form the egg apparatus increase rapidly in size, surround themselves with a delicate cytoplasmic membrane, and begin to assume their characteristic shape. The egg extends from the apex of the sac about one-third its length. The protoplasm is condensed in the basal portion of the egg, and in it lies the nucleus, close to the basal line. Just above the dense cytoplasm is a large vacuole, which occupies fully two-thirds of the entire egg. The synergids are not quite as long as the egg-cell. They are pointed at the apex and broadly oval at the base. The upper portion of each is filled with dense cytoplasm, while the lower one-third of the cell is occupied by a large vacuole, characteristic of synergids in the majority of Angiosperms investigated. The nucleus generally lies in the middle of the cell, surrounded by dense cytoplasm, but quite close to the vacuole (Fig. I 5).

While the egg apparatus is being formed in the micropylar end, various changes are taking place at the antipodal end of the sac. The antipodal polar may be distinguished from the other antipodal cells at an early stage by its greater size and larger nucleus. The usual number of antipodals in Viola is three. Their development and arrangement is varied. In some preparations the antipodals appear as definite cells with distinct limiting membranes, in others the antipodal nuclei lie naked in the general cytoplasm at the base of the sac. The antipodal cells are generally much smaller than those at the micropylar end, but their nuclei are large and, almost without exception, each contains a single nucleolus. These cells may be arranged in a row, side by side, or in a quadrant. As a rule the antipodals are not conspicuous, and in many cases when the embryo-sac is fully mature, the antipodals have already disappeared or are present merely as disintegrated masses at the basal end of the sac. In only one instance observed was there any suggestion of the haustorial development of the antipodals as described for the Rubiaceae (Lloyd, 6), Aster (Opperman, 8), and other genera (Fig. I7).

Soon after the egg apparatus has been established, the polar nuclei move towards each other. The antipodal polar moves more rapidly than the micropylar polar, consequently fusion is often completed just beneath the egg. At first nucleus only fuses with nucleus, and for some time the nucleoli remain distinct. Finally, however, the nucleoli fuse, and the result is a large endosperm nucleus twice the size of either polar nucleus. The 
network of this nucleus is extremely delicate, and only slight condensations of chromatin are visible at the periphery and in the meshes of the net. The endosperm nucleus is very easily recognized, when present, by the large size of its nucleolus. This nucleolus is always characterized by a conspicuous vacuole which very nearly fills it.

\section{Pollination and Development of the Pollen-tube.}

Before the pollen-grain is shed the contents of the microspore divide into a larger and a smaller cell. The smaller or generative cell becomes lenticular and lies free in the cytoplasm of the tube cell (Fig. I 8). Chamberlain (1) and Wylie (9) figure similar generative cells for Salix and Elodea. The pollen-grains lodge on the inner surface of the stigmatic cavity where germination takes place. Often the upper portion of the stylar canal is completely filled with these pollen-tubes, although I could trace comparatively few into the ovary. There is no evidence of branching in the pollen-tube as it passes down the stylar canal, and no penetration of the stylar tissue. The passage of the pollen-tube through the micropyle and between the tapetal cells was clearly observed many times.

The pollen-tubes stain densely at this period, compared with the egg, and in most cases their exact contents could not be determined. From careful observations, I am led to believe that the generative nucleus divides immediately after the entrance of the pollen-tube into the embryo-sac. In cases where the sperm nuclei could be distinguished lying in the densely staining mass emitted from the pollen-tube, they were small, very nearly equal in size, and spherical in outline, giving no suggestion of the spiral form described by so many authors. The nucleus proper stains lightly, but it contains a large, spherical, deeply staining nucleolus.

In Viola, the embryo-sac has reached its mature size previous to the entrance of the pollen-tube (Fig. I5). At this time it is broadest at its middle diameter, narrowing somewhat at the micropylar end, but tapering more conspicuously at the antipodal extremity ; the egg apparatus occupies nearly three-fourths the width and about one-third the length of the sac, and the endosperm nucleus has moved away from the egg, and occupies a central position in the embryo-sac. Following the entrance of the pollentube into the embryo-sac, one or both of the synergids disintegrate, the nucleus of the egg increases in size, and, in some instances, the growth of the antipodal cells is very conspicuous (Fig. I6). In such cases the size and shape of the antipodals recall the antipodal egg described by Chamberlain (12) and by Opperman (11) in Aster, but in no case was there any evidence of fertilization of these cells. Never more than two enlarged cells were found at the antipodal end of the embryo-sac, thus there was never found any structure suggesting an egg apparatus. 
The sperm nuclei, small at first and spherical in outline, increase rapidly in size. One passes down and fuses with the endosperm nucleus. This fusion is clearly shown in Pl. XIX, Fig. 19, in which the endosperm nucleus is easily recognized by the characteristic vacuole of its nucleolus. The sperm nucleus is very large, nearly spherical in outline, and differs from the endosperm nucleus very conspicuously in appearance, in that masses of chromatin are held in the rather close network of the nucleus, and it contains a small densely staining nucleolus. The second sperm enters the egg at its apex. Fusion may take place in the central or in the basal portion of the egg. In both cases the two nuclei are surrounded by a mass of densely staining cytoplasm. Before fusion of the sperm and the egg nucleus is completed, and in some cases before the two nuclei are in contact, the so-called endosperm nucleus divides from one to several times (Figs. 2I, 22). The young endosperm surrounds the egg and outlines a cavity beneath it which extends to the base of the embryo-sac.

This cavity persists in the seed of both the chasmogamic and the cleistogamic flowers when the embryo is fully formed and the seed is nearly mature. The formation of endosperm is very rapid at the last, and in the mature seed we find a solid mass of endosperm surrounding the tiny green embryo at the micropylar end of the seed.

The first division of the egg is transverse, dividing it into two cells nearly equal in size (Fig. 24). There is no suggestion of a suspensor. The oldest embryo figured (Fig. 27) shows a spherical mass of actively dividing cells at the apex of the embryo-sac; the endosperm is limited to a parietal layer lining the embryo-sac, and forming a sheath of cells which completely encloses the embryo, and separates it from the cavity beneath. In mature seeds of the chasmogamic flowers collected and studied in the spring of 1909 , the embryo was an eighth of an inch in length, bright green in colour, and clearly differentiated into radicle, caulicle, and cotyledons.

\section{SUMMARY.}

The primary archesporial cell arises from a hypodermal cell of the nucellus.

A tapetal cell is cut off, which by vertical and transverse divisions forms a cap three or four cells in depth, directly beneath the micropyle.

The definitive archesporial cell divides into an axial row of four cells. The innermost of the four cells is generally the functional megaspore, but cases were observed where the second or third cell of the axial row was enlarging to form the embryo-sac.

The polar nuclei fuse in contact with the egg, generally before the entrance of the pollen-tube.

The synergids are pear-shaped with a large vacuole in the basal portion, and the nucleus lies just above the vacuole. 
The cytoplasm of the egg is condensed at its base, and surrounds the large spherical nucleus.

Fusion of the second sperm with the endosperm nucleus was observed in Viola cucullata.

The endosperm nucleus divides several times before the sexual nuclei have fused, and in some cases before they are in contact.

The first division of the fertilized egg results in the formation of two cells nearly equal in size. There is no suggestion of a suspensor.

As the endosperm increases it forms a sheath around the embryo, and outlines a cavity beneath it which nearly equals in length that of the embryo-sac. This cavity persists until the seed is nearly mature.

In the mature seed the embryo is about an eighth of an inch long, and lies at the micropylar end of the seed surrounded by a solid mass of endosperm. It is bright green and is clearly differentiated into caulicle and cotyledons.

In conclusion, I wish to acknowledge to Professor Ferguson my sincere gratitude for her constant inspiration and invaluable aid throughout this work, and to thank Professor Macfarlane for the many courtesies extended to me during the weeks spent at the University of Pennsylvania.

Wellesley College.

\section{LITERATURE CITED.}

1. Chamberlain, C. J.: Contributions to the Life-history of Salix. Bot. Gazette, xxiii, i897, pp. I 47-79, Pl. XII-XVIII.

2. Coulter, J. M., and Chamberlain, C. J.: Morphology of Angiosperms. D. Appleton \& Co., New York, 1903.

3. Ducamp, L.: Recherches sur l'Embryogénie des Araliacées. Ann. Sci. Nat., Bot., sér. 8, xv, I 902 , pp. 3II-402, Pl. VI-XIII.

4. Ernst, A.: Chromosomenreduction, Entwickelung des Embryosackes und Befruchtung bei Paris quadrifolia, L., und Trillium grandiflorum, Salis. Flora, xci, I902, pp. I-46, P1. I-VI.

5. Juel, H. O.: Beiträge zur Kenntniss der Tetradentheilung. Jahrb. f. wiss. Bot., xxxv, I900, pp. 626-59, Pl. XV, XVI.

6. Lloyd, F. E.: The Comparative Embryology of the Rubiaceae. Mem. Torr. Bot. Club, viii, I902, pp. 27-II 2 , Pl. VIII-XV.

7. Mottier, D. M.: Contributions to the Embryology of the Ranunculaceae. Bot. Gazette, xx, I 895 , pp. 24I-8, 296-304, Pl. XVII-XX.

8. Opperman, K. M. : The Development of the Embryo-sac, Fertilization, and Related Phenomena in Aster. Bot. Gazette, xxxvii, I904, pp. 346-52, Pl. XIV, XV.

9. Wylie, R. B.: The Morphology of Elodea Canadensis. Bot. Gazette, xxxvii, I904, pp. I-22, Pl. I-IV. 


\title{
EXPLANATION OF PLATES XVII-XIX.
}

\author{
Illustrating Miss Bliss's paper on the Life-history of Viola.
}

All figures were drawn with an Abbé camera lucida. The degree of magnification is indicated in the description of each figure. The portion of a figure nearest the micropylar end of the ovule is always towards the top of the plate. The abbreviations used in describing the figures are to be defined as follows: ant., antipodals ; d.a.c., definite archesporial cell; e., egg ; emb.s., embryo-sac; emb., embryo ; end., endosperm; g.n., generative nucleus; i.i., inner integument ; m.m.c., megaspore-mother-cell; meg., megaspore ; $n c$., nucellus ; $n$., nucleus ; mu., nucleolus; $0 . i$., outer integument; p.t., pollen-tube; p.g., pollen-grain ; p.meg., potential megaspore; p.a.c., primary archesporial cell ; s.n., sperm nucleus; s.nu., sperm nucleolus ; Syn., synergids; t.n., tube nucleus ; tap., tapetum.

\section{PLATE XVII.}

Fig. I. Section of upper portion of ovule, showing origin of archesporial cell. $\times 960$. V.odorata.

Fig. 2. Section of upper portion of ovule, showing first division of primary archesporium to form tapetal cell. $\times 960 . \quad V$. odorata.

Fig. 3. Section of nucellus, showing further divisions in tapetum and growth of definite archesporial cell. $\times 960 . \quad V$. cucullata.

Fig. 4. Tip of nucellus, showing late telophase of first division. $\times 960 . \quad V$. pedata.

Fig. 5. Second division of archesporial cell. $\times 960 . V$. cucullata.

Fig. 6. Axial row of four cells arranged in a vertical row. $\times 960 . \quad V$. cucullata.

Figs. 7, 8. Axial row of four cells, showing oblique walls between the cells. $\times 960 . \quad V$. cucullata.

Fig. 9. Tip of nucellus, showing axial row of four cells, upper three disintegrating, lower developing to form embryo-sac. $\times 960 . \quad V$. cucullata.

\section{PLATE XVIII.}

Fig. Io. Axial row of four cells, third developing to form embryo-sac. $\times 960 . \quad$ V. cucullata.

Fig. I I. Axial row of four cells, second developing to form embryo-sac. $\times 960 . \quad V$. cucullata.

Fig. I2. Section of ovule showing two-celled embryo-sac. $\times 960 . \quad V$. pedata.

Fig. I 2 a. Embryo-sac of Fig. I 2. $\times 960$.

Fig. I3. Four-celled embryo-sac. $\times 960 . \quad V$. cucullata.

Fig. 14. Eight-celled embryo-sac. $\times 960 . \quad V$. fimbriatula.

Fig. I5. Mature embryo-sac after fusion of polar nuclei, antipodals disintegrating. $\quad \times 960$. $V \cdot$ pedata.

Fig. 16. Unusual development of antipodals. $\times 960 . \quad V$. cucullata.

Fig. I7. Antipodal portion of embryo-sac, showing slight haustorial development. $\times 960$. $V$. pedata.

Fig. 18. Mature pollen-grain, showing tube-cell and fusiform generative cell. $\times 960$. V. cucullata.

\section{PLATE XIX.}

Fig. I9. Fusion of sperm with endosperm nucleus. $\times 1,200 . \quad V$. cucullata.

Fig. 20. Mature embryo-sac before fusion of sexual nuclei, showing telophase in the first division of the endosperm nucleus. $\times 960 . \quad V$. cucullata.

Fig. 2 I. Embryo-sac, showing fertilization of the egg and four endosperm nuclei.

Fig. 2I $a$. Upper portion of Fig. 2I. $\times 960 . \quad V$. cucullata.

Fig. 22. Embryo-sac, sperm, and egg nuclei not yet in contact. Fourth division of endosperm completed. $\times 49^{\circ}$. V. cucullata.

Fig. 23. First division of the egg. Late anaphase. $\times 1,200 . \quad V$.pubescens.

Fig. 24. Two-celled embryo. $\times 960 . \quad V$. fimbriatula.

Fig. 25. Three-celled embryo. $\times 960 . \quad V$. cucullata.

Fig. 26. Four-celled embryo. $\times 960 . \quad V$. cucullata.

Fig. 27. Multicellular embryo, globular in outline, showing sheath of endosperm. $\times 960$. $V$. pubescens. 

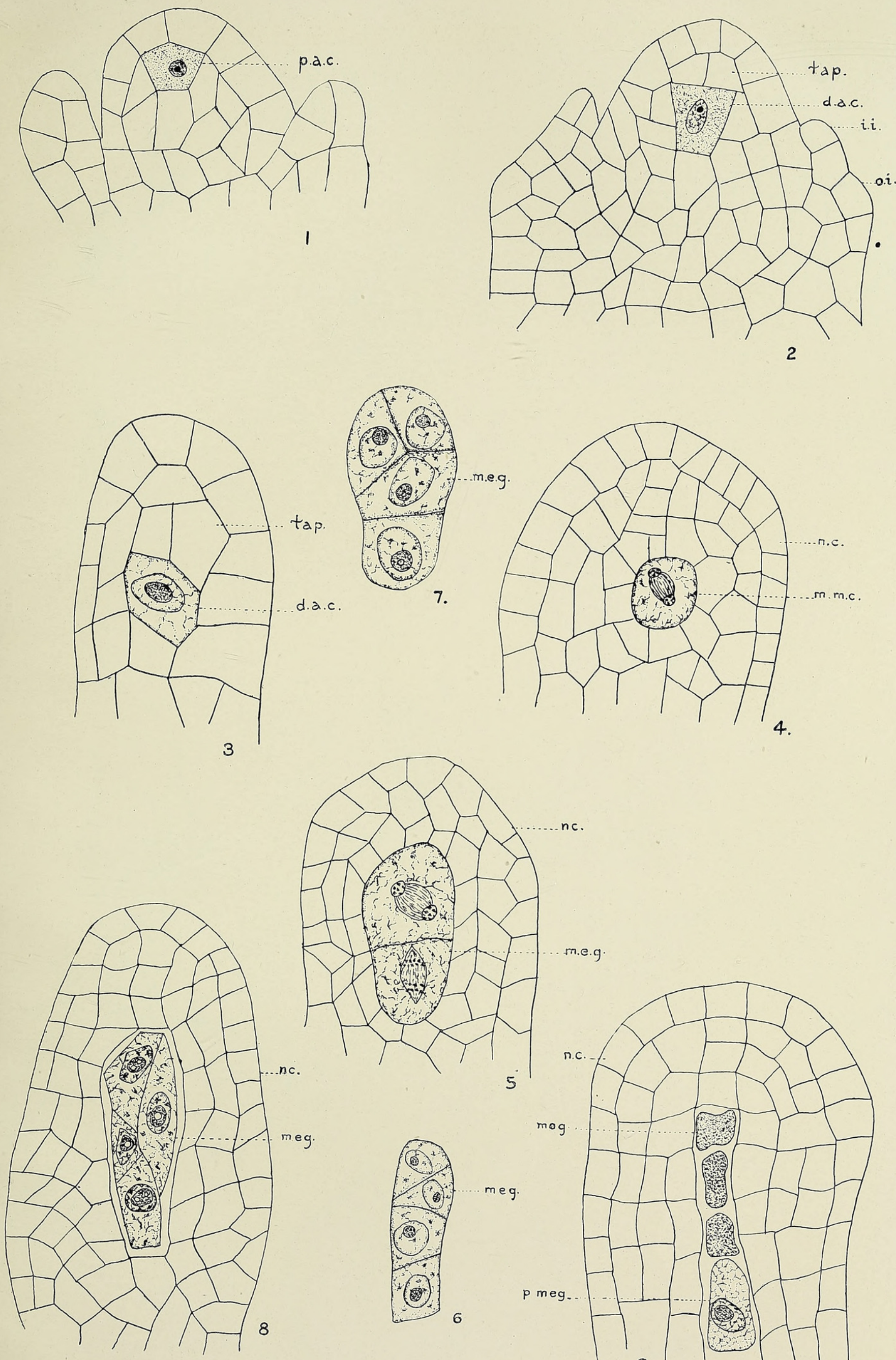

M.C.Bliss del

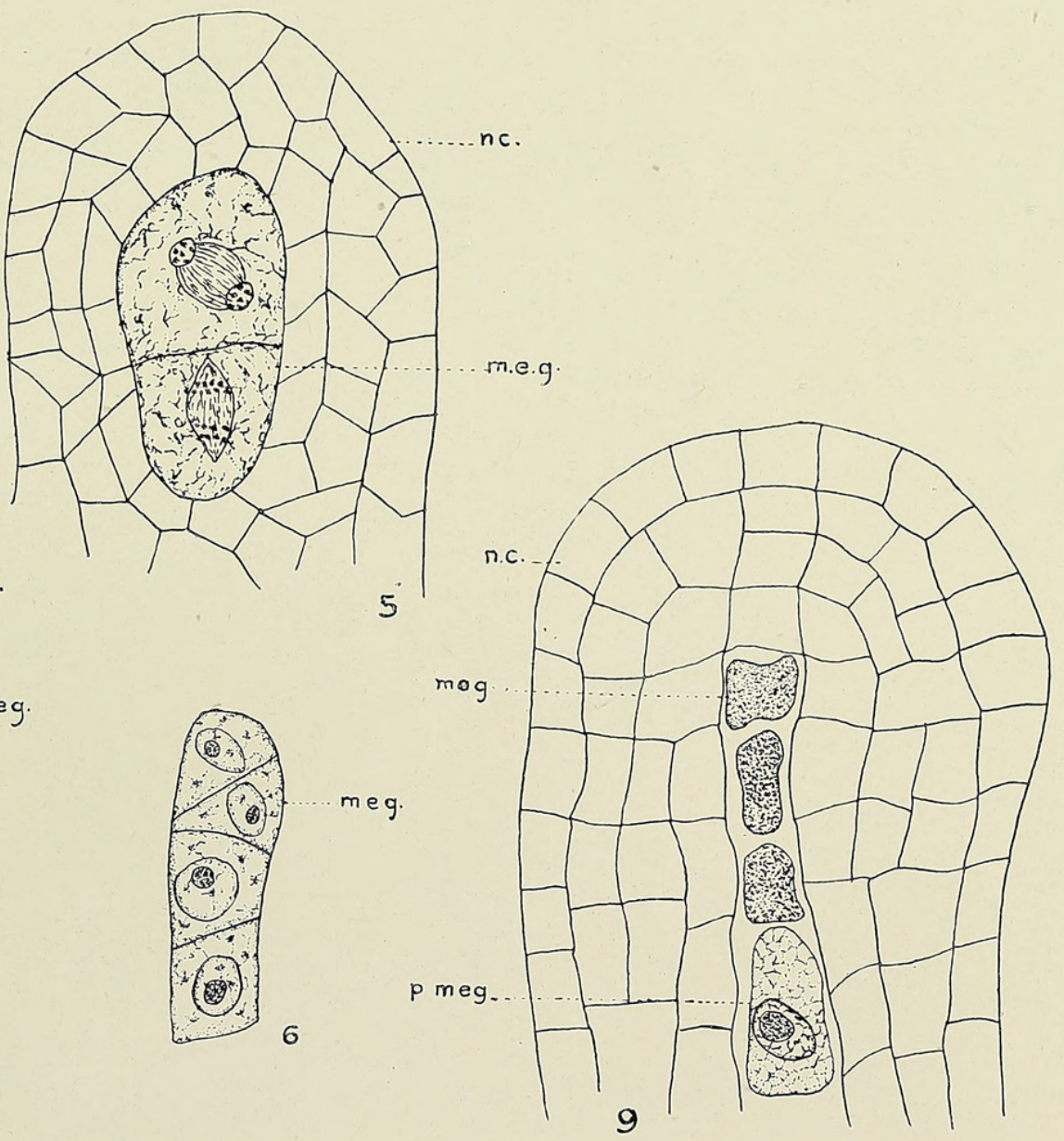

BLISS-VIOLA 
Annals of Botany,

Vol. XXVI, Pl. XVIII.
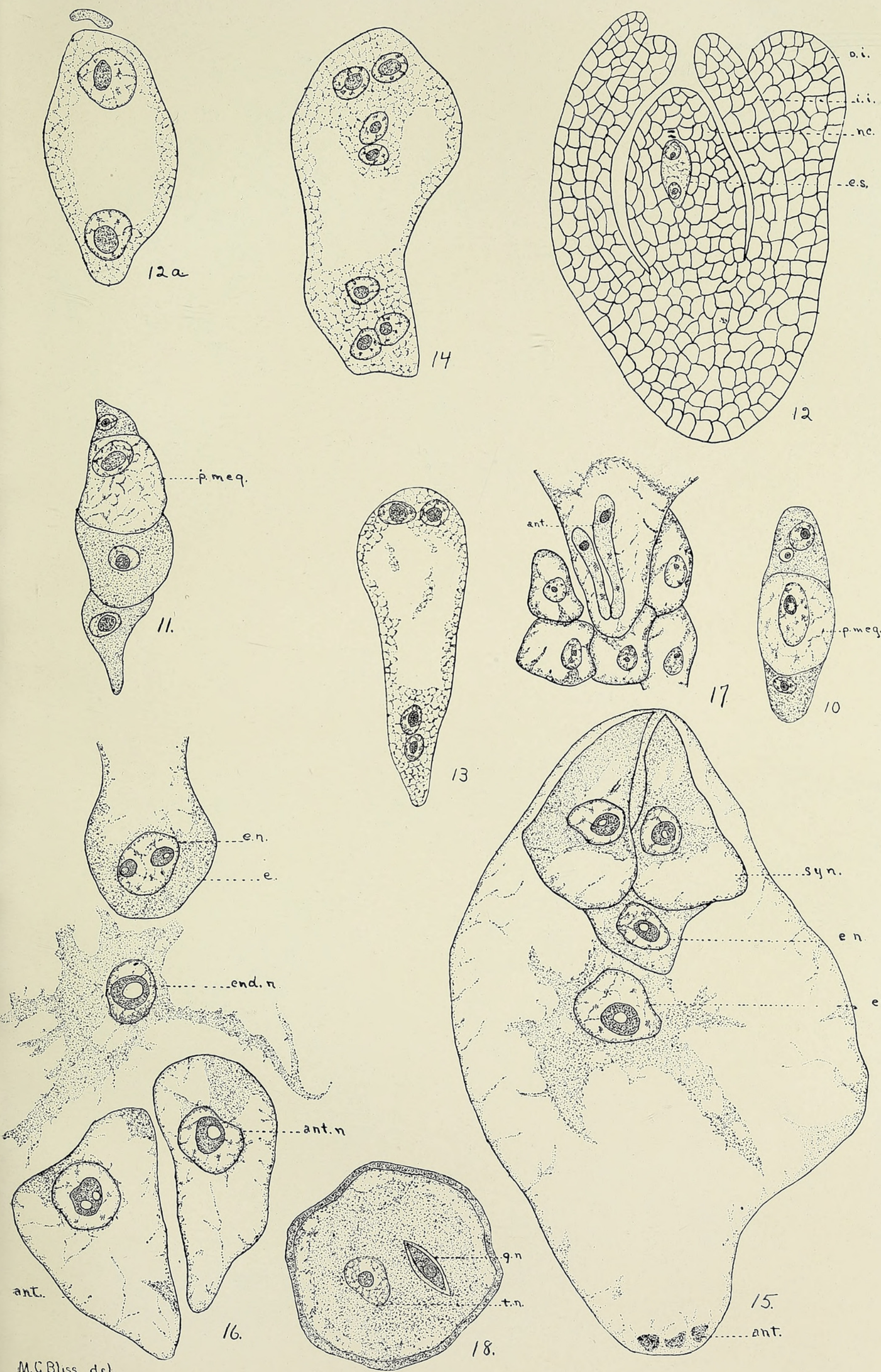

M.CBliss del.
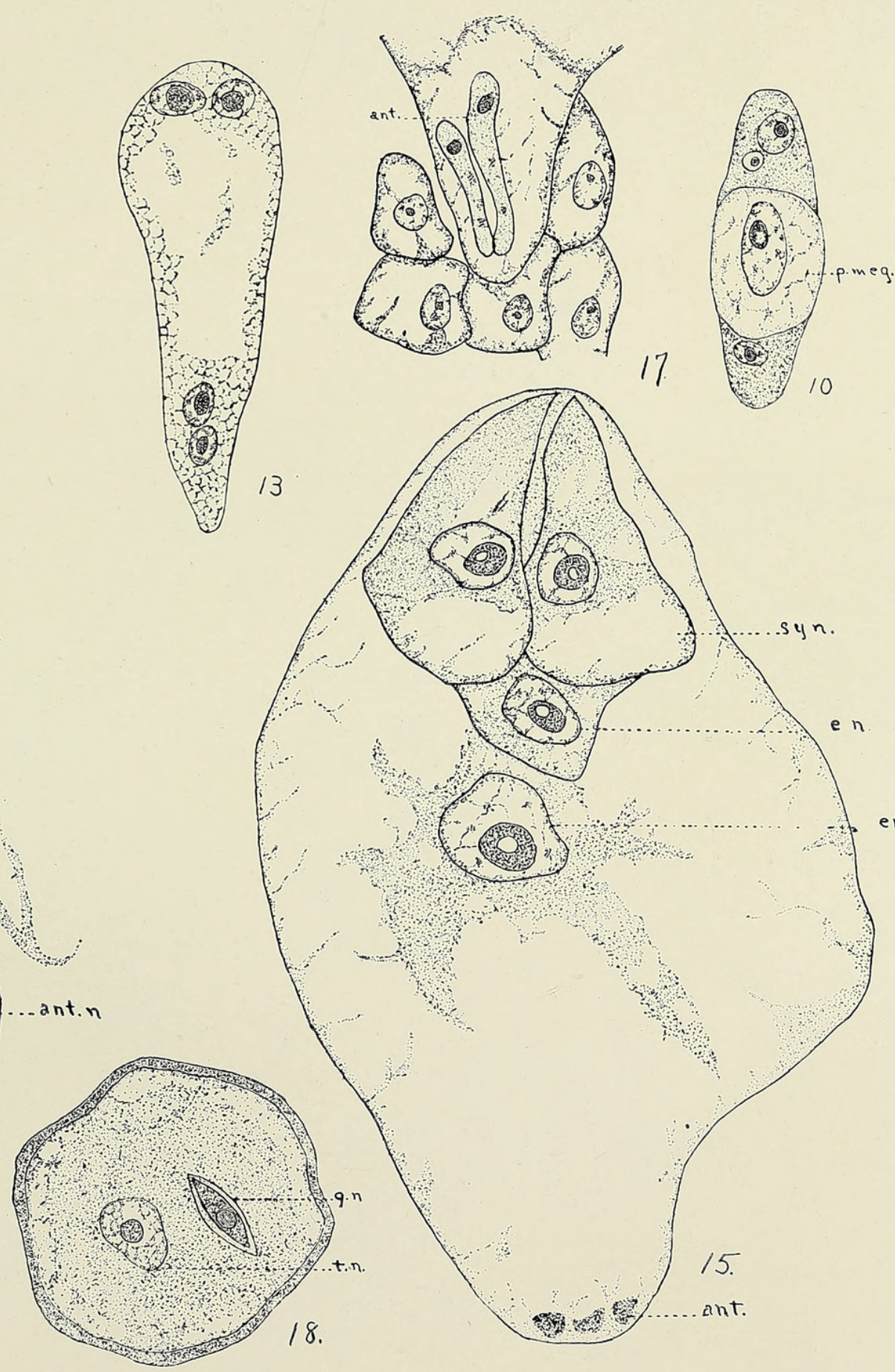

BLISS -VIOLA 


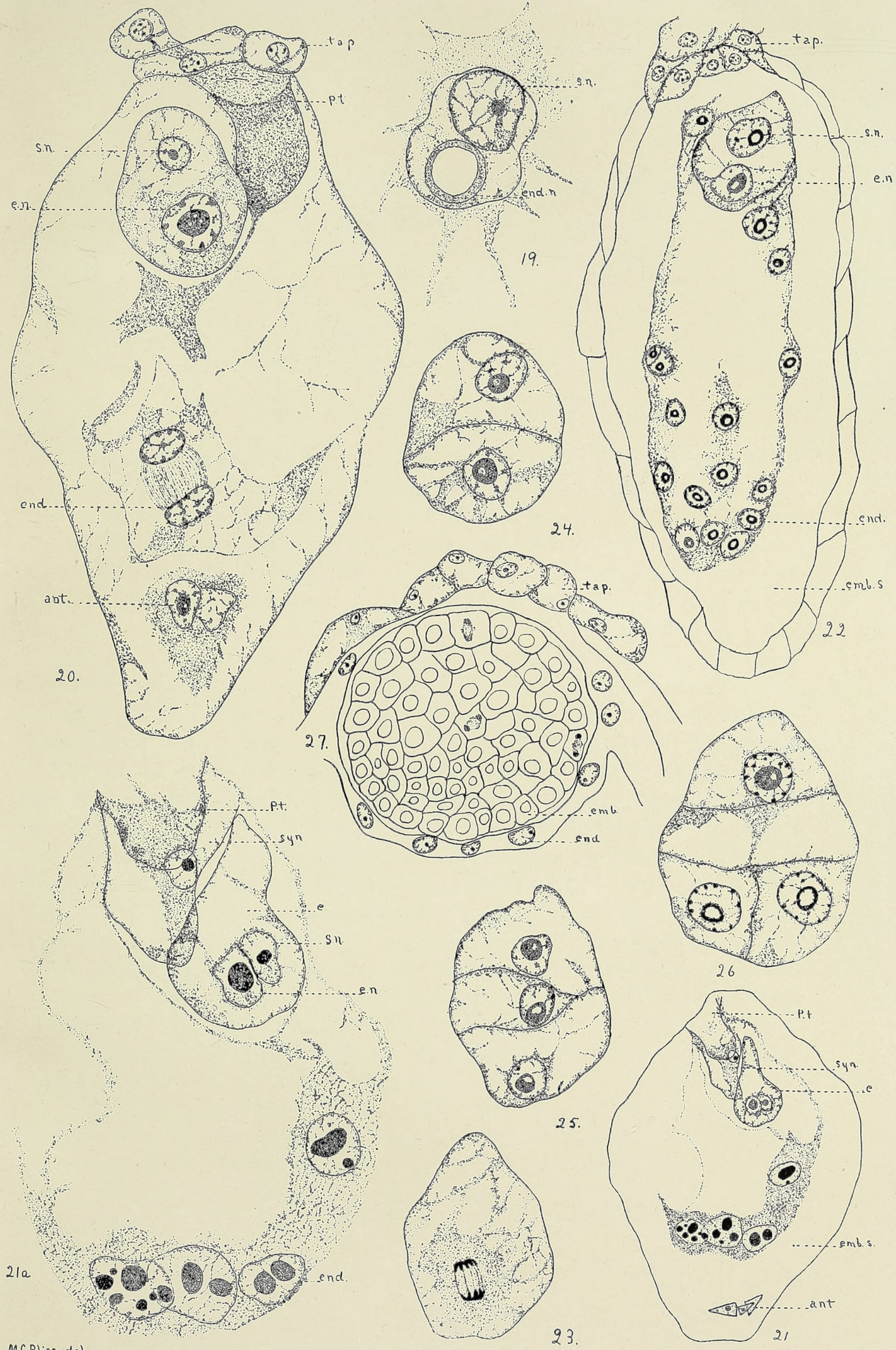




\section{$2 \mathrm{BHL}$ Biodiversity Heritage Library}

Bliss, Mary C. 1912. "A contribution to the life-history of Viola." Annals of botany 26, 155-163. https://doi.org/10.1093/oxfordjournals.aob.a089382.

View This Item Online: https://www.biodiversitylibrary.org/item/236773

DOI: https://doi.org/10.1093/oxfordjournals.aob.a089382

Permalink: https://www.biodiversitylibrary.org/partpdf/319899

\section{Holding Institution}

Smithsonian Libraries

\section{Sponsored by}

Biodiversity Heritage Library

\section{Copyright \& Reuse}

Copyright Status: Not in copyright. The BHL knows of no copyright restrictions on this item.

This document was created from content at the Biodiversity Heritage Library, the world's largest open access digital library for biodiversity literature and archives. Visit BHL at https://www.biodiversitylibrary.org. 